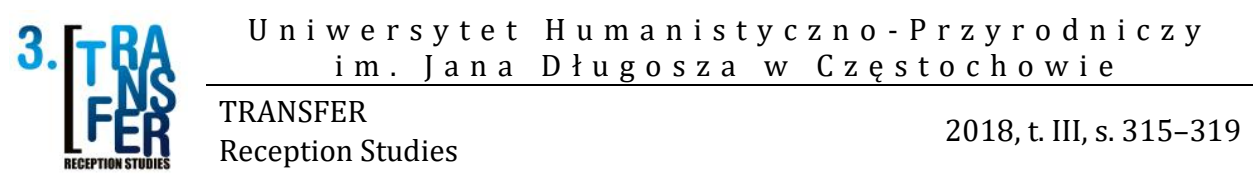

http://dx.doi.org/10.16926/trs.2018.03.15

Joanna ŁAWNIKOWSKA-KOPER

https://orcid.org/0000-0001-7889-8496

Uniwersytet Humanistyczno-Przyrodniczy im. Jana Długosza w Częstochowie (Częstochowa)

\title{
„Lilith spotyka Kalliope. Austria czyta, dyskutuje i tłumaczy" - międzynarodowa konferencja naukowa i warsztaty, Opole 10-11.04.2018
}

\begin{abstract}
Wyjątkowym wydarzeniem obchodów 25-lecia działalności Biblioteki Austriackiej w Opolu była Międzynarodowa Konferencja Naukowa „Lilith spotyka Kalliope. Austria czyta, dyskutuje i tłumaczy”, połączona z warsztatami translatorskimi, a objęta patronatem honorowym Rektora Uniwersytetu Opolskiego, prof. dr. hab. Marka Masnyka, Marszałka Województwa Opolskiego Andrzeja Buły, oraz Ambasadora Republiki Austrii Wernera Almhofera. W dniach 10-11 kwietnia 2018 roku organizatorzy konferencji - Instytut Filologii Germańskiej Uniwersytetu Opolskiego wraz z Biblioteką Austriacką (Österreich-Bibliothek) działającą przy Wojewódzkiej Bibliotece Publicznej w Opolu - gościli wielu dyplomatów (między innymi Panią Ambasador, szefową Departamentu Polityki Kulturalnej z Ministerstwa ds. Europy, Integracji i Spraw Zagranicznych Republiki Austrii dr Teresę Indjein, Ambasadora Republiki Austrii w Polsce Wernera Almhofera, Dyrektora Austriackiego Forum Kultury w Warszawie Ruperta Weinmanna) oraz władze i przedstawicieli środowiska akademickiego Uniwersytetu Opolskiego i Bibliotek Austriackich w Polsce (z Poznania, Rzeszowa i Wrocławia). Wśród zaproszonych gości obecni byli także reprezentanci samorządu województwa opolskiego i środowiska mniejszości niemieckiej.
\end{abstract}


Oryginalne i na długo zapadające w pamięć wprowadzenie do tematu obrad przygotowali studenci opolskiej germanistyki, prowadzeni przez Agnieszkę Klimas z Zakładu Historii Literatury i Kultury Niemiec XIX i XX wieku IFG oraz Emanuelę Jandę. Inspirujący i niezwykle sprawny warsztatowo występ utalentowanych studentek odnosił się do zderzenia dwóch kobiecych żywiołów: reprezentującej pierwiastek racjonalny i świat kultury Kalliope ze starotestamentową pierwszą żoną Adama, symbolizującą naturę i wolość Lilith. Staranna, minimalistyczna charakteryzacja (biel stroju Kalliope vs jaskrawy strój Lilith) i opracowanie muzyczne wzmocniły przekaz inscenizacji opartej na tekstach literackich, podejmujących temat kobiecości: od Fryderyka Hebbla, Artura Schopenhauera, Fryderyka Nietzschego, po Simone de Beauvoir, Virginię Woolf, Olympię de Gouges i Louise Otto Peters. Padające ze sceny słowa wybrzmiały w finale pytaniem o miejsce kobiety w społeczeństwie, kulturze i nauce.

Część naukową konferencji otwarła jej inicjatorka i współorganizatorka profesor dr hab. Andrea Rudolph z Instytutu Filologii Germańskiej Uniwersytetu Opolskiego, stwierdzając, że „wyzwania współczesności pozwalają nadać postaci Lilith, również w konstelacji z Kalliope, nowych znaczeń". W krótkich wystąpieniach zaproszeni goście odnieśli się do idei konferencji i jej szczególnego charakteru. Profesor Katarzyna Lasatowicz, dyrektor IFG UO, podkreśliła rolę współpracy instytucjonalnej i merytorycznej między opolską germanistyka a Biblioteką Wojewódzką w Opolu, podczas gdy dr Teresa Indjein nakreśliła historię i zasługi bibliotek austriackich w świecie, w tym w Polsce, w propagowaniu kultury austriackiej.

Tytuł konferencji „Lilith spotyka Kalliope” to metafora prowokująca do refleksji nad pamięcią kulturową oraz miejscem kobiet w tradycji intelektualnej w Polsce, Austrii i w Niemczech w kontekście problematyki emancypacji kobiet. Otwierając część plenarną, prof. Paul Martin Langner (Uniwersytet Pedagogiczny w Krakowie) przedstawił referat na temat osiągnięć aktorskich Christine Enghaus, żony niemieckiego dramatopisarza i poety Friedricha Hebbla. Reprezentująca Uniwersytet Monachijski dr Barbara Hindinger podjęła tematykę kobiecych wyobrażeń męskości na podstawie wybranych utworów austriackich dramatopisarek - od Marie von EbnerEschenbach, po Elfriede Jelinek i Marlene Streeruwitz. W swym wystąpieniu prof. Johann Sonnleitner (Uniwersytet Wiedeński) podjął temat będący społecznym tabu - mówiąc o fali samobójstw wśród kobiet w okresie międzywojennym, która znalazła swoje odzwierciedlenie w ówczesnej literaturze austriackiej, dokonał analizy towarzyszących temu zjawisku reakcji społecznych. Obrady plenarne zakończyło wystąpienie dr hab. Anny Majkiewicz, prof. AJD (obecnie UJD). Nawiązując do postaci legendarnej Lilith, 
częstochowska badaczka dokonała analizy postaci kobiecych w prozie Elfriede Jelinek z perspektywy przełamywania tabu.

Panel popołudniowy konferencji realizowany był w dwóch sekcjach. Pierwszą, prowadzoną przez prof. Stefana Kaszyńskiego (UAM), rozpoczęło wystąpienie prof. dr hab. Joanny Jabłkowskiej (UŁ), która podjęła kwestie „fantastycznego dokumentaryzmu” i „dokumentarnej fantastyki” w twórczości Kathrin Röggli. Konstrukcje postaci kobiecych w prozie Anny Mitgutsch wnikliwie analizowała dr hab. Joanna Drynda, prof. UAM, a reprezentująca tę samą uczelnię dr hab. Beate Sommerfeld, prof. UAM, przedstawiła problematykę ekfrazy Friederike Mayröcker, nawiązując do dzieł młodych austriackich pisarek. Kończąca pracę sekcji prelekcja dr Ewy CwanekFlorek (Uniwersytet Rzeszowski) przybliżyła słuchaczom ślady obecności znanych Polaków w Wiedniu.

Przebiegające równolegle obrady drugiej sekcji rozpoczęło wystąpienie dr Joanny Ławnikowska-Koper (AJD, obecnie UJD), proponującej w odniesieniu do problematyki konferencji re-lekturę powieści Wir Erben Angeliki Reitzer i namysł nad konstrukcją modeli kobiecości w tym utworze. Dr hab. Artur Pełka (UŁ) ze znawstwem i swadą przedstawił motywy mityczne i religijne $\mathrm{w}$ najnowszych tekstach teatralnych Elfriede Jelinek. Kolejne referaty wygłosiły reprezentantki gospodarzy: dr Gabriela Jelitto-Piechulik (UO) zaprezentowała wpływ państwowości austriackiej na ukształtowanie tożsamości i postawy intelektualnej Ricardy Huch, a Monika WójcikBednarz (UO, Biblioteka Austriacka) omówiła rolę anegdot i humoru żydowskiego w dyskursie pamięci na przykładzie powieści rodzinnej Vienna Evy Menasse.

W drugim dniu obrady konferencji przeniosły się do czytelni Wojewódzkiej Biblioteki Publicznej w Opolu, a rozpoczęła je dyskusja panelowa na temat Roli Bibliotek Austriackich i Austriackiego Forum Kultury w transferze kultury i nauki: Efekt synergii, współpraca, zadania i strategie. W debacie głos zabrali Rupert Weinmann, dyrektor Austriackiego Forum Kultury w Warszawie, Sandra Diepenseifen, kierownik referatu do spraw Bibliotek Austriackich w Ministerstwie Spraw Zagranicznych Republiki Austrii, kierownicy Bibliotek Austriackich: dr Ewa Cwanek-Florek (Rzeszów), Dalia Żminkowska (Wrocław), Aleksandra Wiśniewska i Anna Szewczuk (Poznań) oraz Monika Wójcik-Bednarz (Opole). Prezentacje i dyskusja pozwoliły na wgląd we wszystkie obszary aktywności bibliotek austriackich na świecie, do których należą spotkania autorskie, wystawy, wykłady, wystawy i koncerty oraz spotkania edukacyjne o charakterze popularyzatorskim dla dzieci i młodzieży, a także specjalistyczne sesje i konferencje naukowe oraz działalność wydawnicza bibliotek (Wrocław, Poznań). 
Po dyskusji nastąpiła prezentacja książki Österreichische Literatur zwischen Moderne und Postmoderne (Literatura austriacka od Moderny do Postmoderny) autorstwa prof. Stefana Kaszyńskiego, założyciela i długoletniego kierownika Zakładu Literatury i Kultury Austriackiej UAM. Spotkanie $\mathrm{z}$ autorem moderowała prof. dr hab. Andrea Rudolph. Wskazując na wyróżniający autorów pochodzących z Austrii „kod kulturowy”, wynikający z historii i wielonarodowościowej tradycji, poznański badacz podkreślił szczególne znaczenie dwóch wymienionych w tytule epok dla literatury austriackiej.

Wyjątkowym punktem programu drugiego, warsztatowego dnia opolskiego jubileuszu było spotkanie autorskie z Lydią Mischkulnig. W rozmowie z Moniką Wójcik-Bednarz pisarka opowiedziała o swoich inspiracjach i poglądach na literaturę i kulturę współczesną, a następnie zaprezentowała fragmenty swoich utworów, związanych tematycznie z motywem przewodnim konferencji.

Obchody jubileuszowe zwieńczyły warsztaty translatorskie „Tłumaczenie Austrii", należące już od wielu lat do listy dobrych praktyk współpracy Instytutu Filologii Germańskiej UO oraz opolskiej Biblioteki Austriackiej. Wcześniejsze edycje warsztatów poświęcone były utworom literackim autorów austriackich, w szczególności tych, którzy gościli w Polsce z odczytami (Wolf Wondratschek, Barbara Frischmuth, Sabine Gruber, Carolina Schutti) lub których teksty prezentowane były w formie przedstawień scenicznych (Ingeborg Bachmann, Elfriede Jelinek). W roku jubileuszu Biblioteki Austriackiej w centrum zainteresowania znaleźli się Lydia Mischkulnig (Streifzug oder Moralischer Kater, Die Firma), Maxi Obexer (Europas längster Sommer) oraz Daniel Wisser (Standby, Kein Wort für Blau). Podobnie jak w poprzednich edycjach, celem warsztatów translatorskich było zwrócenie uwagi na specyfikę kulturową Austrii. Honorową opiekę naukową nad warsztatami sprawowała prof. Maria Krysztofiak-Kaszyńska (UAM Poznań), która wygłosiła wstęp poświęcony Tradycji przekładu literatury austriackiej $w$ Polsce. Prezentacji wybranych tłumaczeń, dokonanych przez studentów III roku germanistyki o specjalności translatorskiej oraz I roku studiów magisterskich w zakresie lingwistyki, translatoryki i komunikacji międzykulturowej, towarzyszyła refleksja dotycząca specyficznych cech literatury austriackiej i związanych z nimi szczególnych wyzwań translatorskich, wynikających głównie z indywidualnych założeń poetologicznych i estetyki tekstów poszczególnych autorów. Projekt przygotowała i koordynowała dr Małgorzata Jokiel, pracownik naukowo-dydaktyczny IFG UO.

Dzięki wsparciu Austriackiego Forum Kultury w Warszawie opolskiej konferencji towarzyszyła wystawa „Kalliope w Austrii”, zaprezentowana w holu Studenckiego Centrum Kultury. Plansze przedstawiały osiągnięcia 
kobiet, często zapominanych, niedostrzeganych lub wręcz marginalizowanych, które kształtowały historię Austrii, choć ich nazwiska nie pojawiały się dotąd w oficjalnej historiografii kraju.

Opolska konferencja udowodniła, że Biblioteka Austriacka (Österreich Bibliotek) prowadzona z pasją przez Monikę Bednarz-Wójcik, docenianą w środowisku animatorów kultury, jest nowoczesną, prężną, kreatywną i multifunkcyjną instytucją o profilu kulturalno-edukacyjnym, promującą literaturę austriacką; jest także niezależną instytucją badawczą, będącą w środowisku naukowym Opola ważnym centrum spotkań. Dla części naukowej konferencji stała się forum inspirującej wymiany intelektualnej na nieustannie aktualny i ważny temat samopoznania kobiety, relacji płci i powszechnej emancypacji społeczeństwa. 